\title{
HUBUNGAN PERSEPSI LINGKUNGAN PEMBELAJARAN KLINIK DENGAN PERILAKU CARING PADA MAHASISWA PROFESI NERS
}

\author{
Yenny Tangke Layuk, Totok Harjanto, Elsi Dwi Hapsari \\ Program Studi IImu Keperawatan, \\ Fakultas Kedokteran, Universitas Gadjah Mada, Yogyakarta, 55281, Indonesia \\ E-mail: yennytangkelayuk@gmail.com
}

\begin{abstract}
ABSTRAK
Tujuan: Untuk mengetahui hubungan antara persepsi lingkungan pembelajaran klinik dengan perilaku caring pada mahasiswa Profesi Ners. Metode: Subjek penelitian ialah mahasiswa Profesi Ners satu institusi pendidikan ners di Yogyakarta pada tahun 2012/2013. Responden penelitian berjumlah 61 orang. Alat penelitian yang digunakan ialah kuesioner Clinical Learning Environment and Supervision (CLES) untuk mengetahui lingkungan pembelajaran klinik dan kuesioner Caring Behavior Inventory (CBI) untuk mengetahui perilaku caring. Analisis data menggunakan bivariat korelasi dengan uji korelasi Pearson. Hasil: Suasana ruang perawatan, gaya kepemimpinan, nilai-nilai keperawatan di ruangan, nilai-nilai pembelajaran di ruangan, dan hubungan supervisi paling banyak pada persepsi positif. Subskala gaya kepemimpinan kepala ruangan dengan persepsi positif paling banyak (98,53 persen). Kecenderungan perilaku caring pada mahasiswa Profesi Ners paling banyak pada kategori rendah $(41,0$ persen). Suasana ruang perawatan $(p=0,006)$ dan nilai-nilai keperawatan di ruangan $(p=0,004)$ memiliki hubungan signifikan dengan perilaku caring pada mahasiswa Profesi Ners. Diskusi: Suasana ruang perawatan yang positif dan semangat tim yang baik di lingkungan klinik yang baik dalam menunjang mahasiswa pada hasil dari pembelajaran klinik. Kedua subskala tersebut memiliki hubungan yang signifikan pada perilaku caring pada mahasiswa Profesi Ners satu institusi pendidikan ners di Yogyakarta. Kesimpulan: Persepsi lingkungan pembelajaran klinik yang berhubungan signifikan dengan perilaku caring pada mahasiswa Profesi Ners satu institusi pendidikan ners di Yogyakarta yaitu subskala suasana ruang perawatan dan nilai-nilai keperawatan di ruangan.

Kata Kunci: pembelajaran, klinik, perilaku, caring, profesi.
\end{abstract}

\section{ABSTRACT}

Objective: To learn about the relationship between the perception of the clinical learning environment and caring behavior of the nursing internship students of one institution of nursing education in Yogyakarta. Material and methods: Subject of the research were nursing internship students of one institution of nursing education in Yogyakarta in 2012/2013. Total of the participants were 61 students. The data was collected using the Learning Environment and Supervision (CLES) instrument to learn about clinical learning environment and Caring Behavior Inventory (CBI), an instrument to learn caring behavior. Data was analyzed with using correlation bivariate with Pearson correlation test. Results: The atmosphere of the ward, leadership style, nursing values in the ward, learning values in the ward, and the relationship of the supervisor mostly made positive perception. The leadership style of head nurse of the ward had most positive perception (98,53\%). The tendency of caring behavior of students mostly in low category (41.0\%). The atmosphere at the ward $(p=0,006)$ and values of nursing in the ward $(p=0,004)$ significantly had relation to caring behavior of the nursing internship students of one institution of nursing education in Yogyakarta. Discussion: Positive atmosphere and spirit of the team in the clinical practice field were important to improve outcome of clinical learning for nursing students. Both sub-scales had significant relation to caring behavior to nursing internship students of one institution of nursing education in Yogyakarta. Conclusion: Perception of clinical learning environment that significantly related to caring behavior for nursing internship students of one institution of nursing education in Yogyakarta were the atmosphere and the nursing values in the ward. Keywords: learning, clinic, behavior, caring, internship. 


\section{LATAR BELAKANG}

Caring adalah memberikan perhatian atau penghargaan kepada seorang manusia. Caring juga dapat diartikan memberikan bantuan kepada individu atau sebagai advokasi pada individu yang tidak mampu memenuhi kebutuhan dasarnya.

Berdasarkan penelitian pada tahun 2012 didapatkan lebih dari separuh klien RSUD Pariaman tidak puas terhadap perilaku caring perawat (57,1 persen). Lebih dari separuh klien menilai perilaku caring perawat kurang (66 persen). Penelitian yang dilakukan Yunita di RSUD Pasar Rebo tahun 2011 bila dilihat dari distribusi responden, yaitu per ruangan, diketahui bahwa untuk ruang perawatan Cempaka sebanyak 70,6 persen responden memiliki persepsi kurang caring dan sebanyak 29,4 persen responden memiliki persepsi bahwa perawat di ruang tersebut caring.

Caring dan memelihara lingkungan pendidikan keperawatan merupakan salah satu faktor yang paling penting untuk memberdayakan mahasiswa, yang dicapai melalui kepercayaan, komunikasi terbuka, kejujuran, dan ketulusan antara individu. Dukungan untuk mahasiswa keperawatan selama pengalaman akademis mereka penting untuk membekali mereka agar caring.

Program pendidikan profesi disebut juga sebagai proses pembelajaran klinik. Istilah ini muncul terkait dengan pelaksanaan pendidikan profesi yang sepenuhnya dilaksanakan di lahan praktik seperti rumah sakit, puskesmas, klinik bersalin, panti wredha, dan keluarga serta masyarakat atau komunitas.

Lingkungan pembelajaran klinik merupakan sebuah persepsi mahasiswa terhadap lingkungan belajar klinik yang mencakup suasana ruang perawatan, gaya kepemimpinan kepala ruangan, nilainilai keperawatan di ruangan, nilai-nilai pembelajaran di ruangan, dan hubungan dengan supervisi. Pembelajaran merupakan salah satu proses yang ada di pendidikan klinik. Pembelajaran merupakan suatu proses yang kompleks. Pembelajaran klinik dalam keperawatan merupakan wahana yang memberikan kesempatan kepada mahasiswa untuk menerjemahkan pengetahuan teoretis ke dalam pembelajaran.

Penelitian tentang lingkungan pembelajaran klinik masih sedikit, padahal lingkungan pembelajaran klinik merupakan tempat untuk mahasiswa keperawatan untuk mengaplikasikan ilmunya, dan nantinya mahasiswa dituntut untuk memiliki perhatian, tanggung jawab, dan melakukan segala sesuatunya dengan ikhlas.

\section{METODE}

Jenis penelitian ini ialah noneksperimental. Metode yang digunakan ialah metode analitik korelasi. Rancangan yang digunakan ialah pendekatan cross sectional. Penelitian ini dilaksanakan pada 23 September sampai 6 Oktober 2013 dilakukan di satu institusi pendidikan ners di Yogyakarta. Pengambilan sampel menggunakan teknik total sampling, yaitu berjumlah 61 orang. Lingkungan pembelajaran klinik diukur dengan menggunakan Clinical Learning Environment and Supervision dan skor perilaku caring diukur dengan Caring Behaviour Inventory (CBI). Pengambilan data dilakukan dengan membagikan kuesioner kepada mahasiswa profesi ners pada tahun 2012/2013. Data karakteristik responden dalam penelitian ini ialah usia, jenis kelamin, jumlah anggota keluarga, tempat tinggal, status pernikahan orangtua, orangtua yang masih hidup, pola asuh ayah, pola asuh ibu, IPK akademik, lama belajar di profesi, dan jumlah stase yang kemudian diuji secara univariat. Analisis bivariat korelasi menggunakan uji korelasi Pearson untuk mengetahui hubungan antara lingkungan 
pembelajaran klinik dengan perilaku caring.

\section{HASIL}

Data karakteristik responden dalam penelitian ini ialah usia, jenis kelamin, jumlah anggota keluarga, tempat tinggal, status pernikahan orang tua, orangtua yang masih hidup, pola asuh ayah, pola asuh ibu, IPK akademik, lama belajar di profesi, jumlah stase. Karakteristik responden mahasiswa profesi ners dapat dilihat di Tabel 1.

Tabel 1 menunjukkan bahwa usia responden sebagian besar adalah 23 tahun yaitu sebanyak 40 orang (65,57 persen). Jenis kelamin responden sebagian besar adalah perempuan, yaitu sejumlah 51 orang (82,3 persen). Jumlah anggota keluarga responden paling banyak berjumlah 4 orang, yaitu sebanyak 30 orang (49,18 persen).
Tempat tinggal responden paling banyak tinggal di kos, yaitu sebanyak 55 orang (55,74 persen). Status pernikahan orangtua responden paling banyak tidak bercerai, yaitu sebanyak 58 orang $(95,08$ persen). Orangtua responden yang masih hidup paling banyak kedua orangtua (ayah dan ibu), yaitu sebanyak 55 orang $(90,16$ persen). Pola asuh ayah dan ibu responden paling banyak menerapkan pola asuh authoritative, yaitu masing-masing sebanyak 50 orang (81,97 persen) dan 51 (83,61 persen). IPK akademik responden sebagian besar berada di rentang 3,00-3,50 sebanyak 26 orang (42,62 persen). Responden penelitian paling banyak telah melewati 10 stase selama 53 minggu, yaitu sebanyak 44 orang $(72,13$ persen).

Tabel 1. Distribusi frekuensi karakteristik responden mahasiswa Profesi Ners $(n=61)$

\begin{tabular}{lccc}
\hline \multicolumn{1}{c}{ Karakteristik Responden } & N & $\begin{array}{c}\text { Persentase } \\
(\%)\end{array}$ & Mean \pm SD \\
\hline Usia: & 8 & 13,11 & $23,13 \pm 0,71$ \\
22 tahun & 40 & 65,57 & \\
A 2 tahun & 11 & 18,03 & \\
24 tahun & 1 & 1,64 & \\
25 tahun & 1 & 1,64 & \\
26 tahun & & & \\
\hline Jenis kelamin: & 10 & 16,39 & \\
B Laki-laki & 51 & 83,61 & \\
Perempuan & & & \\
\hline Anggota keluarga: & 2 & 3,28 & $4,61 \pm 1,52$ \\
2 orang & 7 & 11,48 & \\
3 orang & 30 & 49,18 & \\
4 orang & 8 & 13,11 & \\
C orang & 9 & 14,75 & \\
6 orang & 1 & 1,64 & \\
7 orang & 2 & 3,28 & \\
8 orang & 1 & 1,64 & \\
9 orang & 1 & 1,64 & \\
10 orang & &
\end{tabular}




\begin{tabular}{|c|c|c|c|c|}
\hline \multirow{4}{*}{ D } & Tempat tinggal: & & & \\
\hline & Orangtua & 25 & 40,98 & \\
\hline & Kos & 34 & 55,74 & \\
\hline & Sanak saudara & 2 & 3,28 & \\
\hline \multirow{3}{*}{ E } & Status pernikahan orangtua: & & & \\
\hline & Bercerai & 3 & 4,92 & \\
\hline & Tidak bercerai & 58 & 95,08 & \\
\hline \multirow{4}{*}{$\mathbf{F}$} & Orangtua yang masih hidup: & & & \\
\hline & Ayah & 3 & 4,92 & \\
\hline & Ibu & 3 & 4,92 & \\
\hline & Ayah dan ibu & 55 & 90,16 & \\
\hline \multirow{5}{*}{ G } & Pola asuh ayah: & & & \\
\hline & Permissive & 5 & 8,20 & \\
\hline & Authoritarian & 1 & 1,63 & \\
\hline & Authoritative & 50 & 81,97 & \\
\hline & Tidak diasuh & 5 & 8,20 & \\
\hline \multirow{5}{*}{ H } & Pola asuh Ibu: & & & \\
\hline & Permissive & 6 & 9,84 & \\
\hline & Authoritarian & 2 & 3,28 & \\
\hline & Authoritative & 51 & 83,61 & \\
\hline & Tidak diasuh & 2 & 3,28 & \\
\hline \multirow{4}{*}{ I } & IPK akademik: & & & \\
\hline & $<3,00$ & 4 & 6,57 & $3,46 \pm 0,30$ \\
\hline & $3,00-3,49$ & 26 & 42,62 & \\
\hline & $\geq 3,50$ & 31 & 50,81 & \\
\hline \multirow{4}{*}{$J$} & Lama belajar di profesi: & & & \\
\hline & 53 minggu & 44 & 72,13 & $44,80 \pm 13,94$ \\
\hline & 33 minggu & 7 & 11,48 & \\
\hline & 17 minggu & 10 & 16,39 & \\
\hline \multirow{4}{*}{ K } & Jumlah stase: & & & \\
\hline & 10 stase & 44 & 72,13 & $8,51 \pm 2,637$ \\
\hline & 7 stase & 7 & 11,48 & \\
\hline & 3 stase & 10 & 16,39 & \\
\hline
\end{tabular}

Sumber: data primer

1. Persepsi Lingkungan Pembelajaran Klinik pada Mahasiswa Profesi Ners

Distribusi responden terhadap persepsi lingkungan pembelajaran klinik dapat dilihat pada Tabel 2. 
Tabel 2. Distribusi frekuensi, nilai rata-rata (mean), standar deviasi (SD), dan median persepsi responden terhadap lingkungan pembelajaran klinik

\section{$\begin{array}{lllll}\text { Lingkungan Pembelajaran Klinik N } & \text { Persentase } & \text { Mean } \pm \text { SD } & \text { Median }\end{array}$}

(\%)

Suasana ruang perawatan

A. 1 Positif:
A.1.1 Laki-laki
$9 \quad 14,75$
$3,75 \pm 0,35$
3,75
38
62,30
$3,58 \pm 0,43$
3,75

A A.1.2 Perempuan

A. 2 Negatif:
A.2.1 Laki-laki
1
1,64
2,75
2,75
A.2.2 Perempuan
13
21,31
$2,53 \pm 0,22$
2,50

Gaya kepimpinan kepala ruangan

B.1 Positif:

$\begin{array}{llllll} & \text { B.1.1 Laki-laki } & 10 & 16,39 & 4,05 \pm 0,28 & 4,00 \\ \text { B } \quad \text { B.1.2 Perempuan } & 50 & 81,97 & 3,95 \pm 0,44 & 4,00\end{array}$

B.2 Negatif:

\begin{tabular}{|c|c|c|c|c|c|}
\hline & B.2.1 Laki-laki & 0 & 0 & 0 & 0 \\
\hline & B.2.2 Perempuan & 1 & 1,64 & 2,00 & 2,00 \\
\hline & \multicolumn{5}{|c|}{ Nilai-nilai keperawatan di ruangan } \\
\hline & \multicolumn{5}{|c|}{ C.1 Positif: } \\
\hline & C.1.1 Laki-laki & 8 & 13,11 & $3,49 \pm 0,30$ & 3,49 \\
\hline \multirow[t]{7}{*}{ C } & C.1.2 Perempuan & 43 & 70,49 & $3,73 \pm 0,39$ & 3,66 \\
\hline & \multicolumn{5}{|l|}{ C.2 Negatif: } \\
\hline & C.2.1 Laki-laki & 2 & 3,28 & 2,66 & 2,66 \\
\hline & C.2.2 Perempuan & 8 & 13,11 & $2,24 \pm 0,29$ & 2,16 \\
\hline & \multicolumn{5}{|c|}{ Nilai-nilai pembelajaran di ruangan } \\
\hline & \multicolumn{5}{|c|}{ D.1 Positif : } \\
\hline & D.1.1 Laki-laki & 9 & 14,75 & $3,66 \pm 0,33$ & 3,83 \\
\hline \multirow[t]{7}{*}{ D } & D.1.2 Perempuan & 42 & 68,85 & $3,59 \pm 0,35$ & 3,66 \\
\hline & \multicolumn{5}{|l|}{ D.2 Negatif: } \\
\hline & D.2.1 Laki-laki & 1 & 1,64 & 2,83 & 2,83 \\
\hline & D.2.2 Perempuan & 9 & 14,75 & $2,51 \pm 0,30$ & 2,50 \\
\hline & \multicolumn{5}{|l|}{ Hubungan supervisi } \\
\hline & \multicolumn{5}{|l|}{ E.1 Positif: } \\
\hline & E.1.1 Laki-laki & 10 & 16,39 & $3,68 \pm 0,32$ & 3,62 \\
\hline $\mathbf{E}$ & E.1.2 Perempuan & 44 & 72,13 & $3,65 \pm 0,38$ & 3,62 \\
\hline \multicolumn{6}{|c|}{ E.2 Negatif: } \\
\hline & E.2.1 Laki-laki & 0 & 0 & 0 & 0 \\
\hline & E.2.2 Perempuan & 7 & 11,48 & $2,57 \pm 0,33$ & 2,75 \\
\hline
\end{tabular}

Hasil penelitian pada Tabel 2 banyak pada persepsi positif. Hasil persepsi menunjukkan bahwa setiap subskala responden pada lima subskala lingkungan lingkungan pembelajaran klinik paling pembelajaran klinik persepsi positif paling 
banyak pada subskala gaya kepimpinan dan perempuan sebanyak 50 orang $(81,97$ kepala ruangan, yaitu laki-laki sebanyak 10 persen) dengan nilai mean 3,95. orang (16,39 persen) dengan nilai mean 4,05

\section{Hubungan Jumlah Stase dengan Persepsi Lingkungan Pembelajaran Klinik}

Hubungan jumlah stase yang telah dijalani dengan persepsi lingkungan pembelajaran klinik mahasiswa pada profesi dapat dilihat pada tabel 3.

Tabel 3. Analisis hubungan lingkungan pembelajaran klinik dengan jumlah stase yang telah dijalani pada mahasiswa Profesi

\begin{tabular}{|c|c|c|c|c|c|}
\hline \multirow{3}{*}{$\begin{array}{c}\text { Lingkungan } \\
\text { Pembelajaran Klinik }\end{array}$} & \multicolumn{3}{|c|}{$\begin{array}{c}\text { Jumlah Stase yang sudah } \\
\text { Dijalani }\end{array}$} & \multirow{3}{*}{ Mean $\pm S D$} & \multirow{3}{*}{$p^{*}$} \\
\hline & 10 Stase & 7 Stase & 3 Stase & & \\
\hline & $f(\%)$ & $f(\%)$ & $f(\%)$ & & \\
\hline
\end{tabular}

Suasana ruang perawatan

\begin{tabular}{|c|c|c|c|c|c|}
\hline \multirow[t]{2}{*}{ A } & A.1 Positif & $37(60,66)$ & $5(8,20)$ & $5(8,20)$ & $3,63 \pm 0,41 \quad 0,01$ \\
\hline & A. 2 Negatif & $7(11,48)$ & $2(3,28)$ & $5(8,20)$ & $2,55 \pm 0,22$ \\
\hline
\end{tabular}

Gaya kepimpinan kepala ruangan

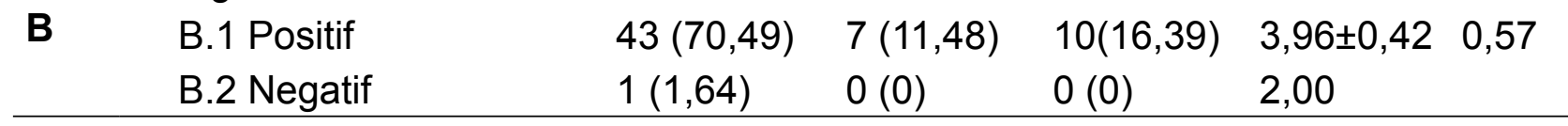

\begin{tabular}{|c|c|c|c|c|c|c|}
\hline \multirow[b]{3}{*}{ C } & \multicolumn{6}{|l|}{$\begin{array}{l}\text { Nilai-nilai keperawatan di } \\
\text { ruangan }\end{array}$} \\
\hline & C.1 Positif & $36(59,02)$ & $6(9,84)$ & $9(14,75)$ & $3,69 \pm 0,39$ & 0,52 \\
\hline & C.2 Negatif & $8(13,11)$ & $1(1,64)$ & $1(1,64)$ & $2,33 \pm 0,31$ & \\
\hline & \multicolumn{6}{|l|}{$\begin{array}{l}\text { Nilai-nilai pembelajaran di } \\
\text { ruangan }\end{array}$} \\
\hline \multirow[b]{2}{*}{ D } & D.1 Positif & $35(57,38)$ & $6(9,84)$ & $10(16,39)$ & $3,60 \pm 0,35$ & 0,11 \\
\hline & D.2 Negatif & $9(14,75)$ & $1(1,64)$ & $0(0)$ & $2,54 \pm 0,30$ & \\
\hline \multirow{3}{*}{ E } & Hubungan supervisi & & & & & \\
\hline & E.1 Positif & $38(62,30)$ & $7(11,48)$ & $9(14,75)$ & $3,66 \pm 0,36$ & 0,60 \\
\hline & E.2 Negatif & $6(9,84)$ & $0(0)$ & $1(1,64)$ & $2,57 \pm 0,33$ & \\
\hline
\end{tabular}

${ }^{*}$ nilai $p$ didapatkan dari nilai jumlah responden variabel lingkungan pembelajaran klinik dengan variabel jumlah stase yang sudah dijalani.

Hasil penelitian pada Tabel 3 Suasana ruang perawatan merupakan menunjukkan persepsi responden tentang komponen yang terdapat hubungan yang lingkungan pembelajaran klinik paling signifikan dengan jumlah stase yang dijalani banyak berada pada persepsi positif dengan karena didapatkan nilai $p=0,01(p<0,05)$. responden yang telah melewati 10 stase. 


\section{Perilaku Caring}

Perilaku caring pada mahasiswa Profesi Ners dapat dilihat pada Tabel 4 di bawah ini.

Tabel 4. Distribusi frekuensi, nilai rata-rata (mean), dan standar deviasi (SD) tingkat kecenderungan perilaku caring pada mahasiswa Profesi Ners

\begin{tabular}{lccc}
\hline $\begin{array}{c}\text { Tingkat Kecenderungan Perilaku } \\
\text { Caring Mahasiswa }\end{array}$ & $\begin{array}{c}\text { Frekuensi } \\
(\mathbf{f})\end{array}$ & $\begin{array}{c}\text { Persentase } \\
(\%)\end{array}$ & Mean \pm SD \\
\hline Tinggi & 18 & 29,51 & $156,89 \pm 8,45$ \\
Sedang & 18 & 29,51 & $137,06 \pm 3,605$ \\
Rendah & 25 & 41,98 & $126,20 \pm 3,08$ \\
\hline
\end{tabular}

HasilpenelitianpadaTabel4 menunjukkan bahwa tingkatan kecenderungan perilaku caring pada mahasiswa Profesi Ners paling banyak pada kategori rendah, yaitu sebanyak 25 orang $(41,98$ persen $)$.
Analisis karakteristik responden dengan tingkat kecenderungan perilaku caring menunjukkan tidak ada satu pun karakteristik responden yang berhubungan dengan perilaku caring pada mahasiswa Profesi Ners (lampiran).

\section{Hubungan Persepsi Lingkungan Pembelajaran Klinik dengan Perilaku Caring}

Tabel 5. Analisis hubungan variabel lingkungan pembelajaran klinik dengan tingkat kecenderungan perilaku caring pada mahasiswa Profesi Ners

\begin{tabular}{|c|c|c|c|}
\hline & $\begin{array}{c}\text { Variabel Lingkungan } \\
\text { Pembelajaran Klinik }\end{array}$ & $\begin{array}{c}\text { Tingkat Perilaku caring } \\
\text { mean } \pm S D\end{array}$ & $\mathbf{P}^{*}$ \\
\hline & Suasana ruang perawatan & & \\
\hline \multirow[t]{2}{*}{ A } & Positif & $140,68 \pm 13,90$ & 0,006 \\
\hline & Negatif & $131,00 \pm 11,30$ & \\
\hline \multirow{3}{*}{ B } & Gaya kepimpinan & & \\
\hline & Positif & $138,00 \pm 13,52$ & 0,182 \\
\hline & Negatif & 166,00 & \\
\hline & Nilai-nilai keperawatan di ruang & & \\
\hline \multirow[t]{2}{*}{ C } & Positif & $140,10 \pm 14,30$ & 0,044 \\
\hline & Negatif & $130,10 \pm 7,43$ & \\
\hline \multirow{3}{*}{ D } & Nilai-nilai pembelajaran di ruan & & \\
\hline & Positif & $139,02 \pm 13,89$ & 0,450 \\
\hline & Negatif & $135,60 \pm 14,20$ & \\
\hline \multirow{3}{*}{ E } & Hubungan supervisi & & \\
\hline & Positif & $139,54 \pm 14,31$ & 0,127 \\
\hline & Negatif & $130,14 \pm 5,21$ & \\
\hline
\end{tabular}


Hasil penelitian pada Tabel 5 didapatkan bahwa dari 5 subskala lingkungan pembelajaran klinik yang berhubungan signifikan dengan perilaku caring $(p<0,05)$, yaitu subskala suasana ruang keperawatan, diperoleh nilai $p=0,006$ dan subskala nilainilai keperawatan di ruangan dengan nilai $p=0,044$.

\section{DISKUSI}

Karakteristik responden berdasarkan usia sebagian besar adalah 23 tahun karena mahasiswa profesi pada tahun ini paling banyak lulusan dari angkatan tahun 2008 yang mayoritas lahir tahun 1990. Jenis kelamin responden sebagian besar adalah perempuan. Hal ini terkait dengan lokasi penelitian, yang mayoritas mahasiswanya adalah perempuan. Tempat tinggal responden paling banyak tinggal di kos. Hal ini terkait mayoritas mahasiswa profesi ners berasal dari luar Yogyakarta.

Suasana ruang perawatan, gaya kepimpinan, nilai-nilai keperawatan di ruangan, nilai-nilai pembelajaran di ruangan, dan hubungan supervisi paling banyak pada persepsi positif. Lingkungan pembelajaran klinik yang positif karena adanya persepsi mahasiswa terhadap kesempatan untuk mempraktikkan dan persepsi mahasiswa terhadap kejelasan peran, mengidentifikasi enam faktor sebagai determinan penting yang mempengaruhi persepsi perawat terhadap lingkungan pembelajaran di rumah sakit yaitu: kemandirian dan pengakuan; kepuasan kerja; kejelasan peran; kualitas pengawasan dukungan rekan; dan kesempatan belajar. Manajer bangsal mampu merangsang dan memperkuat partisipasi dan komitmen untuk sebuah jangkauan yang luas dari pengalaman pembelajaran mahasiswa keperawatan.

Lingkungan pembelajaran klinik paling banyak berada pada persepsi positif dengan responden yang telah melewati 10 stase.
Hasil penelitian ini hampir sama dengan penelitian yang dilakukan oleh Nugroho (2009), yakni persepsi lingkungan akademik lebih banyak pada persepsi positif dan berada pada angkatan yang telah melewati lebih banyak stase profesi ners. Hal ini terkait bahwa persepsi terhadap lingkungan klinik berhubungan secara signifikan dengan pendekatan belajar, yakni mahasiswa yang telah lebih banyak melewati stase profesi ners sehingga ilmu dan pengetahuan yang diterima lebih mendalam (deep approach) mempunyai persepsi yang positif terhadap lingkungan pembelajaran klinik dan kepuasan yang lebih tinggi dibandingkan dengan mahasiswa yang baru melewati beberapa stase profesi ners atau baru mulai di stase awal sehingga ilmu yang diterima kurang mendalam atau hanya baru sebagian saja (surface approach). Pengalaman lingkungan pembelajaran klinik adalah entitas sosial yang kompleks yang dapat memengaruhi hasil belajar siswa di pengaturan klinis. Pengalaman ini dapat memberikan wawasan tentang fungsi pendidikan di klinis dan dapat untuk meningkatkan kesempatan mahasiswa untuk belajar. Subskala yang memiliki hubungan yang signifikan dengan jumlah stase ialah suasana ruang perawatan. Hal ini terkait durasi atau lamanya penempatan klinis pada ruang perawatan mempunyai pengaruh yang signifikan terhadap kemampuan siswa dalam pemahaman yang jelas terhadap kemampuan siswa dalam pemahaman yang jelas tentang peran perawat, siswa dapat belajar mengenali unsur-unsur penting dalam berinteraksi dengan pasien dan pembimbing klinik.

Tingkat perilaku caring pada mahasiswa profesi ners paling banyak pada kategori rendah. Hal tersebut dapat terjadi karena perilaku itu sendiri dapat dipengaruhi oleh beberapa faktor, baik dari dalam individu maupun luar individu. Caring harus 
dipertimbangkan dalam hubungan dengan orang lain dan hal ini melibatkan karakteristik personal, kognitif, dan kemampuan teknis. Hasil penelitian Karaoz (2009) menunjukkan bahwa untuk memperjelas persepsi mahasiswa keperawatan tentang perilaku caring, diperlukan adanya professional/ helping relationship dan kompetensi teknis. Perilaku tumbuh seiring dengan pertumbuhan seseorang sejak lahir hingga meninggal dunia. Dari karakteristik responden tidak ada satu pun yang didapatkan berhubungan signifikan dengan perilaku caring mahasiswa Profesi Ners.

Lingkungan pembelajaran klinik dengan perilaku caring mahasiswa profesi ners, bahwa dari 5 subskala lingkungan pembelajaran klinik yang berhubungan signifikan dengan perilaku caring, yaitu subskala suasana ruang keperawatan dan subskala nilai-nilai keperawatan di ruangan dan ini juga dapat dilihat dari rata-rata tingkat perilaku caring untuk masing-masing subskala lingkungan pembelajaran klinik bahwa subskala suasana ruang perawatan dan nilai-nilai keperawatan di ruangan memiliki rata-rata perilaku caring positif paling tinggi dibandingkan dengan 3 subskala yang lainnya (gaya kepimpinan, nilai-nilai pembelajaran di ruangan, dan hubungan supervisi). Suasana ruang perawatan yang baik dicirikan seperti mempertunjukkan kerja tim dan komunikasi yang baik. Apabila staf bangsal bekerja sama dan ada motivasi, mahasiswa merasa didukung dan diawasi. Suasana ruang perawatan yang positif dan semangat tim yang baik merupakan ciri paling penting dari lingkungan klinik yang baik dalam menunjang mahasiswa keperawatan pada hasil dari pembelajaran klinik. Suatu lingkungan pembelajaran dapat menunjang proses pembelajaran bagi mahasiswa dimulai dengan dirumuskannya secara jelas tujuan yang akan dicapai oleh mahasiswa selama berada di ruangan. Hal ini akan membantu mahasiswa untuk lebih memahami dan menyadari keberadaan mereka, peran mereka, dan apa yang akan mereka capai selama penempatan klinik, termasuk memahami arti pemberian pelayanan kepada pasien sehingga pelayanan yang diberikan bermakna dan berkualitas. Layanan keperawatan yang berkualitas tinggi merupakan konteks terbaik untuk pengalaman pembelajaran yang sukses.

Penelitian yang dilakukan Hasan (2012) menunjukkan tanggapan yang positif terhadap nilai-nilai perawatan di ruangan disebabkan telah terbinanya hubungan yang saling membutuhkan antara staf dengan mahasiswa dan pasien. Layanan perawatan dilakukan dengan semangat untuk merawat maka mahasiswa dapat mempelajari inti dari layanan keperawatan melalui pengalaman layanan mereka. Hal ini didukung oleh Kososwski (1995) yang menyatakan melalui layanan mereka dengan pasien, kepercayaan diri mahasiswa dan harga diri mahasiswa dalam memberikan pelayanan keperawatan dapat ditingkatkan.

Subskala lingkungan pembelajaran klinik yang tidak memiliki hubungan yang signifikan dengan perilaku caring ialah gaya kepimpinan, nilai-nilai pembelajaran di ruangan, dan hubungan supervisi. Lingkungan klinik yang baik terdiri atas komponen praktis, misalnya familiarisasi atau hubungan kekeluargaan, situasi pembelajaran yang penuh arti, dan adanya umpan balik. Komponen tersebut akan meningkatkan pengembangan profesional. Pengembangan profesional adalah sebuah proses sosio-budaya yang luas di mana masing-masing individu mengasumsikan nilai, perilaku, pemahaman moral, dan informasi dari kelompok. Pembimbing klinik dalam hal ini berperan sebagai nurse teacher memiliki peran penting untuk mendukung kesempatan belajar mahasiswa 
selama penempatan klinis. Nurse teacher mempunyai peran yang sangat besar dalam membantu mahasiswa belajar selama praktik klinik.

Tujuan sistem pengawasan ialah untuk menciptakan sebuah hubungan yang erat antara pembimbing klinik dan mahasiswa, memberikan dukungan pada individu dan panduan pada pembelajaran klinik dan berkontribusi terhadap pengembangan profesional mereka. Mahasiswa yang merasa diperhatikan selama dalam lingkungan pembelajaran dapat mengembangkan rasa aman sehingga membuatnya lebih mudah untuk belajar, mengubah perilaku, dan mengambil risiko.

Perilaku caring itu sendiri dapat dipelajari melalui role model sejak dalam masa pendidikan. Caring dapat diperkenalkan sejak awal kurikulum dan di lingkungan pembelajaran akademik. Pengajar (dosen) juga dapat menjadi role model caring untuk mahasiswa selama proses pembelajaran sehingga mahasiswa akan lebih merasakan dan mudah untuk belajar dan mengubah perilaku.

Pada penelitian ini responden yang berjenis kelamin laki-laki rata-rata perilaku caring-nya lebih tinggi daripada jenis kelamin perempuan. Hal yang sama juga ditunjukkan pada penelitian yang dilakukan oleh Feizal (2012) yang menujukkan bahwa tidak ada perbedaan dalam kecenderungan perilaku caring antara mahasiswa profesi laki-laki dan perempuan di jurusan keperawatan, derajat perilaku caring mungkin bervariasi antara jenis kelamin, tetapi semua tergantung kebiasaan yang ditanamkan sejak dini di dalam keluarga. Tidak ada penemuan yang konsisten mengenai perbedaan gender dalam perilaku caring itu sendiri (Lengua dan Stormsha, 2000).

Responden yang berusia 23 tahun rata-rata perilaku caring-nya $(140,68)$ lebih tinggi daripada usia yang lain dan tidak terdapat hubungan yang signifikan dengan perilaku caring. Hal ini berbeda dari penelitian yang dilakukan oleh Murphy, dkk (2009) yang menunjukkan bahwa ada perbedaan dalam kecenderungan perilaku caring yang diukur dengan $\mathrm{CBI}$ berdasarkan umur pada mahasiswa keperawatan. Hal ini bisa disebabkan karena umur responden mayoritas berumur 23 tahun.

Rata-rata untuk perilaku caring yang paling tinggi untuk jumlah anggota keluarga ialah yang berjumlah 2 orang, yaitu nilainya 148,50 walaupun tidak ada hubungan yang signifikan. Responden yang tinggal bersama orangtuanya memiliki kecenderungan perilaku caring tinggi yang paling banyak, yaitu sebanyak 6 orang ( 9,83 persen). Hal ini terkait lingkungan keluarga yang dapat membantu remaja dalam mengembangkan perilaku caring. Orangtua dapat membicarakan hal-hal tersebut sehingga mereka akan merasa puas dari pengalaman tersebut (Alaska ICE, 2007), tetapi tidak ada hubungan yang signifikan dengan perilaku caring.

Responden yang orangtuanya bercerai ternyata rata-rata perilaku caringnya $(146,33)$ lebih tinggi daripada yang orangtuanya tidak bercerai. Untuk pola orangtua yang ayahnya menerapkan pola asuh permissive dan ibu yang menerapkan pola asuh authoritative memiliki rata-rata perilaku caring paling tinggi, yaitu masingmasing 146,20 dan 139,47. Hal yang sama juga ditunjukkan oleh penelitian yang dilakukan oleh Yuniatun (2009) bahwa tidak terdapat hubungan antara pola asuh ayah atau ibu dengan kecenderungan perilaku caring mahasiswa.

Responden penelitian yang memiliki IPK di bawah 3 rata-rata perilaku caring-nya $(141,77)$ lebih tinggi daripada responden yang memiliki IPK di atas 3. Mahasiswa yang telah menjalani program profesi selama 53 minggu atau telah melewati 10 stase memiliki 
rata-rata perilaku caring yang paling tinggi, yaitu 139,34. Raines (2007) menunjukkan bahwa terjadi peningkatan kemampuan individu untu care kepada orang lain selama berubahnya tingkat studi. Pada mahasiswa yang baru tingkat awal, caring-nya tergolong sedang, sedangkan pada tingkat akhir caring-nya tergolong tinggi.

\section{SIMPULAN}

Persepsi lingkungan pembelajaran klinik paling banyak pada persepsi positif. Variabel lingkungan pembelajaran klinik persepsi positif paling banyak pada subskala gaya kepemimpinan kepala ruangan. Tingkat perilaku caring pada mahasiswa profesi ners paling banyak pada tingkat rendah. Variabel lingkungan pembelajaran klinik yang berhubungan signifikan dengan perilaku caring mahasiswa Profesi Ners di satu institusi pendidikan ners di Yogyakarta, yaitu subskala suasana ruang keperawatan dan subskala nilai-nilai keperawatan di ruangan.

\section{DAFTAR PUSTAKA}

Association of Alaska School Boards Alaska Initiative for Community Engagement (Alaska ICE). 2007. Asset Building: Helping Kids Succeed-Alaskan Style. Retrieved from: www.bens.ac.th/health/. Diakses tanggal 18 Juli 2013.

Emilia, O. 2008. Kompetensi Dokter dan Lingkungan Belajar Klinik di Rumah Sakit. Yogyakarta: Gadjah Mada University Press.

Feizal, M.G. 2012. "Perbedaan Perilaku Caring antara Mahasiswa Profesi Ners Laki-Laki dan Perempuan Jurusan Keperawatan FKIK Universitas Jenderal Soedirman". Tesis. Universitas Jenderal Soedirman, Purwokerto. Retrieved from: http://keperawatan.unsoed.ac.id. Diakses tanggal 16 Juli 2013.

Hafsyah, L. 2012. "Hubungan Perilaku Caring yang Dilakukan Perawat dengan
Tingkat Kepuasaan Klien di Ruangan Penyakit Dalam RSUD Pariaman Tahun 2012". Artikel Padang. Retrieved from: http://repository.unand.ac.id Diakses tanggal 16 Juli 2013

Hasan, S.M. 2012. Hubungan Antara Persepsi Mahasiswa Terhadap Lingkungan Belajar Klinik Dengan Pencapaian Kompetensi Praktik Klinik Keperawatan di Akademi Keperawatan Luwuk. Tesis (tidak diterbitkan). UGM, Yogyakarta.

Herdianti, H. Y. 2012. "Evaluasi Pasca Pelatihan Perilaku Caring pada Perawat di Unit Rawat Inap Rumah Sakit Umum Daerah Pasar Rebo Tahun 2011". Tesis (tidak diterbitkan). UII, Yogyakarta.

Karaoz, S. 2009. "Turkish Nursing Students' Perception of Caring". Nurse Education Today, 25 (1):31-40.

Murphy, F., Jones, S., Edwards, M., James, J., Mayer, A. 2009. "The Impact of Nurse Education on The Caring Behaviours of Nursing Students". Nurse Education Today, 29 (2): 254-264.

Notoatmodjo, S. 2007. Promosi Kesehatan dan IImu Perilaku. Jakarta: Rineka Cipta. Nugroho, A.T. 2009. "Persepsi Mahasiswa terhadap Lingkungan Pendidikan Program Studi Pendidikan Dokter Fakultas Kedokteran Universitas Gadjah Mada". Skripsi (tidak diterbitkan). UGM, Yogyakarta.

Nursalam. 2008. Pendidikan dalam Keperawatan. Jakarta: Salemba.

Oerman, M.H., Heinrich, K.T. 2005. "Annual Review of Nursing Education". Strategies for Teaching, Assesment, and Program Planning. Volume 3. USA: Spinger Publishing Company.

Papastavrou, E., Lambrinou, E., Tsangari, H., Saarikoski, M., Leino-Kilpi, H. 2010. "Student Nurses Experience of Learning in The Clinical Environment". Nurse Education in Practice, 10, 17-182. 
Raines, D.A. 2007. "Caring Abilities of Students in an Accelerated Program of Study: A Program Evaluation Study". International Journal of Human Caring; 11 (3): 45-49. Retrieved from: http:// works.bepress.com/. Diakses tanggal 18 Februari 2013.

Saarikoski, M., Warme, T., Kaila, P., Leino, H. 2009. "The Role of The Nurse Teacher in Clinical Learning Practice: An Empirical Study of Finish Student Nurse Experiences". Nurse Education Today, 29:595-600.

Warne, T., Johannsson, U., Papastavrou, E., Tichelaar, E., Tomietto, M., Bossche, K. V. D., Moreno, M. F. V., Saarioski, M. (2010). "An Exploration of The Clinical
Learning Experience of Nursing Student in Nine European Countries". Nurse Education Today, 30:809-815.

Wessel, J., Larin, H., Benson, G., Brown, B., Ploeg, J., Wiliams, R., Marting, L. 2008. "Emotional-Social Intelligence in Health Science Students and Its ralation to Leadership, Caring, and Moral Judgement". Journal of Allied health Science and Practice, 6(1):1-8.

Yuniatun, W. 2009. "Hubungan Pola Asuh Orang Tua dengan Kecenderungan Perilaku Caring pada Mahasiswa Program A Angkatan 2008/2009 PSIK FK UGM". Skripsi (tidak diterbitkan). UGM, Yogyakarta. 


\section{LAMPIRAN}

Analisis karakteristik responden dengan tingkat kecenderungan perilaku caring pada mahasiswa Profesi Ners

\begin{tabular}{|c|c|c|c|c|c|c|}
\hline & \multirow{3}{*}{$\begin{array}{l}\text { Karakteristik } \\
\text { Responden }\end{array}$} & \multicolumn{3}{|c|}{ Tingkat Kecenderungan Perilaku Caring } & \multirow{3}{*}{ Mean $\pm S D$} & \multirow{3}{*}{$p^{*}$} \\
\hline & & Tinggi & Sedang & Rendah & & \\
\hline & & $f(\%)$ & $f(\%)$ & $f(\%)$ & & \\
\hline & Jenis kelamin: & & & & & \\
\hline \multirow[t]{3}{*}{ A } & Laki-laki & $3(4,92)$ & $3(4,92)$ & $4(6,56)$ & $140,30 \pm 17,28$ & 0,952 \\
\hline & Perempuan & $15(24,59)$ & $15(24,59)$ & $21(34,43)$ & $138,10 \pm 13,29$ & \\
\hline & Usia: & & & & & \\
\hline \multirow[t]{6}{*}{ B } & 22 tahun & $1(1,64)$ & $3(4,92)$ & $4(6,56)$ & $133,13 \pm 7,53$ & \\
\hline & 23 tahun & $15(24,59)$ & $8(13,11)$ & $17(27,87)$ & $140,68 \pm 15,62$ & 0,846 \\
\hline & 24 tahun & $2(3,28)$ & $6(9,84)$ & $0(0)$ & $135,82 \pm 9,537$ & \\
\hline & 25 tahun & $0(0)$ & $0(0)$ & $3(4,92)$ & 123,00 & \\
\hline & 26 tahun & $0(0)$ & $1(1,64)$ & $1(1,64)$ & 137,00 & \\
\hline & Anggota keluarga: & & & & & \\
\hline \multirow[t]{10}{*}{ C } & 2 orang & $1(1,64)$ & $0(0)$ & $3(4,92)$ & $148,50 \pm 26,16$ & 0,783 \\
\hline & 3 orang & $1(1,64)$ & $1(1,64)$ & $5(8,20)$ & $130,57 \pm 13,08$ & \\
\hline & 4 orang & $9(14,75)$ & $8(13,11)$ & $13(21,31)$ & $138,63 \pm 13,86$ & \\
\hline & 5 orang & $4(6,56)$ & $3(4,92)$ & $1(1,64)$ & $144,13 \pm 14,07$ & \\
\hline & 6 orang & $3(4,92)$ & $5(8,20)$ & $1(1,64)$ & $142,67 \pm 12,16$ & \\
\hline & 7 orang & $0(0)$ & $0(0)$ & $1(1,64)$ & 126,00 & \\
\hline & 8 orang & $0(0)$ & $1(1,64)$ & $1(1,64)$ & $130,00 \pm 5,65$ & \\
\hline & 9 orang & $0(0)$ & $0(0)$ & $1(1,64)$ & 131,00 & \\
\hline & 20 orang & $0(0)$ & $0(0)$ & $1(1,64)$ & 122,00 & \\
\hline & Tempat tinggal: & & & & & \\
\hline \multirow[t]{4}{*}{ D } & Orangtua & $11(18,03)$ & $6(9,84)$ & $8(13,11)$ & $136,21 \pm 12,91$ & 0,403 \\
\hline & Kos & $6(9,84)$ & $12(19,67)$ & $16(26,23)$ & $140,88 \pm 14,09$ & \\
\hline & Sanak-saudara & $1(1,64)$ & & $1(1,64)$ & $146,50 \pm 28,99$ & \\
\hline & Status pernikahan: & & & & & \\
\hline \multirow[t]{2}{*}{$\mathbf{E}$} & Bercerai & $2(3,28)$ & $1(1,64)$ & $0(0)$ & $146,33 \pm 12,58$ & 0,098 \\
\hline & Tidak bercerai & $16(26,23)$ & $17(27,87)$ & $25(40,98)$ & $138,05 \pm 13,92$ & \\
\hline \multirow[t]{4}{*}{$\mathbf{F}$} & $\begin{array}{l}\text { Orangtua yang } \\
\text { masih hidup: }\end{array}$ & & & & & \\
\hline & Ayah dan ibu & $16(26,23)$ & $18(29,51)$ & $21(34,43)$ & $138,33 \pm 13,19$ & 0,530 \\
\hline & Ayah & $1(1,64)$ & $0(0)$ & $2(3,28)$ & $141,67 \pm 20,20$ & \\
\hline & lbu & $1(1,64)$ & $0(0)$ & $2(3,28)$ & $137,67 \pm 25,71$ & \\
\hline
\end{tabular}




\begin{tabular}{|c|c|c|c|c|c|c|}
\hline \multirow{5}{*}{ G } & Pola asuh ayah: & & & & & \\
\hline & Permissive & $2(3,28)$ & $2(3,28)$ & $1(1,64)$ & $146,20 \pm 18,75$ & 0,520 \\
\hline & Authoritarian & $0(0)$ & $0(0)$ & $1(1,64)$ & 130,00 & \\
\hline & Authoritative & $14(22,95)$ & $16(26,23)$ & $20(32,79)$ & $137,68 \pm 12,76$ & \\
\hline & Tidak diasuh & $2(3,28)$ & $0(0)$ & $3(4,92)$ & $140,20 \pm 20,99$ & \\
\hline \multirow{5}{*}{ H } & Pola asuh ibu: & & & & & \\
\hline & Permissive & $2(3,28)$ & $2(3,28)$ & $2(3,28)$ & $136,50 \pm 12,89$ & 0,580 \\
\hline & Authoritarian & $1(1,64)$ & $0(0)$ & $1(1,64)$ & $130,50 \pm 12,02$ & \\
\hline & Authoritative & $16(26,23)$ & $16(26,23)$ & $20(32,79)$ & $139,47 \pm 14,19$ & \\
\hline & Tidak diasuh & $0(0)$ & $0(0)$ & $2(3,28)$ & $126,50 \pm 4,95$ & \\
\hline \multirow{4}{*}{ I } & IPK akademik: & & & & & \\
\hline & $\geq 3,50$ & $11(18,03)$ & $11(18,03)$ & $9(14,75)$ & $134,00 \pm 12,02$ & 0,20 \\
\hline & $3,00-3,49$ & $6(9,84)$ & $5(8,20)$ & $15(24,59)$ & $135,19 \pm 12,86$ & \\
\hline & $<3,00$ & $1(1,64)$ & $2(3,28)$ & $1(1,64)$ & $141,77 \pm 14,49$ & \\
\hline \multirow[t]{5}{*}{ J } & $\begin{array}{l}\text { Lama belajar di } \\
\text { profesi: }\end{array}$ & & & & & \\
\hline & 53 minggu & $14(22,95)$ & $13(21,31)$ & $17(27,87)$ & $139,34 \pm 14,55$ & 0,928 \\
\hline & 33 minggu & $1(1,64)$ & $1(1,64)$ & $5(8,20)$ & $138,40 \pm 12,09$ & \\
\hline & 17 minggu & $3(4,92)$ & $4(6,56)$ & $3(4,92)$ & $133,00 \pm 12,27$ & \\
\hline & Jumlah stase: & & & & & \\
\hline \multirow[t]{3}{*}{ K } & 10 & $14(22,95)$ & $13(21,31)$ & $17(27,87)$ & $139,34 \pm 14,55$ & 0,928 \\
\hline & 7 & $1(1,64)$ & $1(1,64)$ & $5(8,20)$ & $138,40 \pm 12,09$ & \\
\hline & 3 & $3(4,92)$ & $4(6,56)$ & $3(4,92)$ & $133,00 \pm 12,27$ & \\
\hline
\end{tabular}

